\title{
EFFECT OF SOLVENT TYPE ON THE EXTRACTED BIOACTIVE COMPOUNDS OF MALLOW (MALVA SYLVESTRIS) LEAVE
}

\author{
M. E. El-Sayed, M.A. Salem and I. M. Eisa \\ Food Science and Technology Dept, Fac. of Agric., Tanta Univ., Egypt \\ Received: Mar. 8, 2018 \\ Accepted: Apr. 24, 2018
}

\begin{abstract}
The effect of different extraction solvents (water, $70 \%$ ethanol and $95 \%$ methanol) on bioactive compounds (polyphenols, flavonoids and saponinand tanins) and antioxidant characteristics of mallow leaves extracts were investigated The total phenolic compounds extracted from green parts of mallow using $70 \%$ ethanol, $95 \%$ methanol and water were $57.2,43.2$ and $121.6 \mathrm{mg} / \mathrm{g}$, respectively. The total flavonoids content of mallow water extract is significantly $(p \leq 0.05)$ higher than those of methanolic and ethanolic extracts. Tannins content in mallow extract obtained by $70 \%$ ethanol was $15.52 \mathrm{mg}$ tannic/g which was significantly higher than the other solvents, meanwhile the lowest amount (4.9 mg tannic/g) was detected in 95\% methanolic extract. The same trened was also found for saponin, since the highest value $(6.7 \mathrm{mg} / \mathrm{g})$ was in $70 \%$ ethanolic extract. Total antioxidant capacity (TAC) of mallow extracts at 500ppm decreased as the

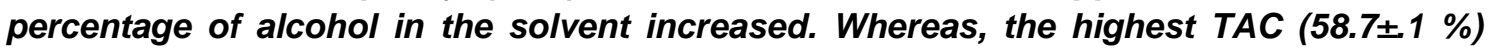
was detected in water extract and decreased gradually by decreasing the percentage of water in the solvent. the water extract at $500 \mathrm{ppm}$ had significantly higher ( $p \leq 0.05)$ antioxidant activity compared to the other solvents. Consequently, the water was the best solvent for extraction phenolics and flavonoids from green parts of mallow and these extracts have a strong antioxidant activity
\end{abstract}

Key words: Mallow extract, antioxidants, phenolic, DPPH

\section{INTRODUCTION}

Malva sylvestris is a species of the genus Malva in the family of Malvaceae and is considered to be the type species for the genus. It is known as common mallow or mallow to English speaking (Milin et al., 2003 and Yeole et al., 2010). Plant polyphenols are aromatic hydroxylated compounds, commonly found in vegetables, fruits and many food sources that form a significant portion of our diet, and which are among the most potent and therapeutically useful bioactive substances. Phenolic derivatives represent the largest group known as 'secondary plant products' synthesized by higher plants, probably as a result of antioxidative strategies adapted in evolution by respirative organisms starting from precursors of cyanobacteria (Bennick, 2002). Mallow extracts are reported for their radical scavenging effect (Karakaya, 2004). Oxidation Different reports in the literatures displayed that extracts of either edible or non-edible plant materials have antioxidant effect owing to the presence of some active phytochemicals, especially, phenolic compounds (Lako et al., 2007; Pellegrini et al., 2007, Benavente et al., 2000, Emmons and Peterson, 1999). On the other hand, plant material wastes from food industries involve high which has an adverse environmental impact. Thus, considerable importance on the recovery, recycling and upgrading of food industry wastes to decrease the environmental pollution (Laufenberg et al, 2003; Reddy and Yang, 2005). Mallow can be considered as good sources of some phenolic and antioxidant compounds (Beghdad et al., 2014). Malva sylvestris L. is one of the most promising medicinal plant species. However, extensive 
research in the area of isolation and characterization of the active compounds of $M$. sylvestris is essential so that better, safer, and cost-effective drugs for curing various diseases and infections can be developed (Paul, 2016). The objective of this work was to evaluate the effect of different extraction solvents on the yield, bioactive compounds and antioxidant properties of mallow.

\section{MATERIAL AND METHODS}

\section{Materials}

The green leaves of mallow (Malva sylvestris) were collected from the farm at Etay-Elbarod city, El-Behera governorate, Egypt, season 2015. They were cleaned by water, air dried in oven at $\left(40^{\circ} \mathrm{C}\right.$ to $\left.50^{\circ} \mathrm{C}\right)$ and grinded using an electric blender. The powder of sample was kept in polyethylene bags and preserved in deep freezer at $\left(-18^{\circ} \mathrm{C}\right)$ until use.

All chemicals, solvents used in this study were purchased from El- Gomhoria Company of Chemicals and Drugs, Tanta City, Egypt.

\section{Methods}

\subsection{Determination of proximate chemical composition}

Moisture content, crude protein content, Ether extract, Ash andcrude fiber were determined as described in the A.O.A.C. (2005). All analyses were carried out in triplicates and the values were expressed as the mean \pm standard deviation $(\mathrm{M} \pm \mathrm{SD})$ on dry weight basis. Total carbohydrates content was calculated by subtracting protein, ash and ether extract contents from the total mass of $\mathbf{1 0 0}$ and available carbohydrates were calculated by subtracting crude fiber content from total carbohydrates as reported by Tadrus (1989).

\subsection{Preparation of mallow extract \\ Extract of mallow was prepared from ground dried green leaves using different}

solvents $(70 \%$ ethanol, $95 \%$ methanol and water) at ratio of 1 to $10 \mathrm{w} / \mathrm{v}$ the extraction was carried out in an orbital shaker at room temperature $\left(22 \pm 2{ }^{\circ} \mathrm{C}\right)$ for $24 \mathrm{hrs}$. After that, the extract was separated by filtration using Whatman No.1 filter paper. The filtered extract was kept in deep freezer at $-18{ }^{\circ} \mathrm{C}$ until use Charles et al. (1993). To determine the extraction yield of samples, $10 \mathrm{ml}$ of the extract was evaporated under vacuum in rotary evaporator at $45^{\circ} \mathrm{C}$ and weighted.

\subsection{Determination of total phenolic compounds content:}

Total phenolic content in the extracts were determined spectophotometrically using folin-ciocalteau reagent according to the procedure of Thaipong et al. (2006). the stander curve was prepared using gallic acid.

\subsection{Determination of total flavonoids}

Total flavonoids were determined according to Vuong et al. (2014). The quercetin was used to prepare the stander curve.

\subsection{Identification and quantification of phenolics and flavonoids by HPLC}

Constituents of phenolics and flavonoids of mallow sample were identification and quantified using HPLC technique in National Research Center, Cairo, Egypt according to the method outlined by Evangelisti et al., (1997).

\subsection{Determination of total tannins content.}

Tannins content of samples was estimated by using Folin-Danis method (Schanderi, 1970). The absorbance was measured by spectrophotometer (T80+UV/VIS) at $700 \mathrm{~nm}$. The standard curve was produced by using of tannic acid and the results were expressed as 
$\mathrm{mg}$ of tannic acid equivalent per $\mathrm{g}$ of dry sample (mg TAE/g).

\subsection{Determination of total saponins:}

Total saponins content was estimated according to the method described by Hiai et al., (1975) using $8 \%$ vanillin in ethanol and $72 \%$ sulphoric acid. The standard curve was produced by using of cholesterol and the results were expressed as $\mathrm{mg}$ of saponins equivalent per $g$ of dry sample.

\subsection{Determination of antioxidant capacity by phospomolybdenum method}

The antioxidant capacity of the Malva sylvestris extract was evaluated by the phosphor molybdenum method according to the procedure of Prieto et al., (1999). The assay based on the reduction of molybdenum (VI) to molybdenum (V) by the antioxidant compounds and subsequent formation the green phosphate-molybdenum (V) complex, which has a maximal absorption at $695 \mathrm{~nm}$ at acidic $\mathrm{pH}$. The antioxidant activity is expressed as $\mathrm{mg}$ equivalent of ascorbic acid at $500 \mathrm{ppm}$.

\subsection{Scavenging activity on DPPH free radical}

The ability of a compound to donate a hydrogen atom was assessed on the basis of the scavenging activity of the stable 2,2-diphenyl-2-picrylhydrazyl
(DPPH) radical that was determined according to the procedure of Lim and Quah (2007). The antioxidant activity was calculated according to the following equation at (100ppm, 200ppm, 300ppm and 500ppm):

$\%$ radical scavenging activity $=[1-(A$

$$
\text { sample } \left.\left./ A_{\text {control }}\right)\right] \times 100
$$

Where: $A=$ is absorbance at $517 \mathrm{~nm}$

\subsection{Statistical analysis}

Data are represented as the means \pm standard error of mean (SE) for three replicates calculated by Microsoft excel. Analysis of variance (ANOVA) was applied for evaluating the significant of variances due to the used treatments of $(p \leq 0.05)$ and the differences between means were further tested using the Dunc's and LSD squires multiple ranges. All the statistical methods were as outlined by SAS (2002-2003).

\section{RESULTS AND DISCUSSION}

\section{Chemical composition of mallow green parts}

As shown in Table (1), green parts of mallow leaves contain $74.2 \%$ moisture, $8.5 \%$ crude protein, $3.58 \%$ ether extract, $4.58 \%$ ash, $5.65 \%$ crude fiber and $77.69 \%$ available carbohydrates (on dry weight basis). These results indicate that green parts of mallow are rich in carbohydrates and ash content while they contain a moderate content of protein and low content of ether extract.

Table (1): Proximate chemical composition of mallow green parts (dry weight)

\begin{tabular}{|l|l|}
\hline Chemical composition & Amount \% \\
\hline Moisture & $74.22 \pm 0.301$ \\
\hline Ether extract & $3.58 \pm 0.120$ \\
\hline Crude protein & $8.50 \pm 0.1$ \\
\hline Crude fibre & $5.65 \pm 1.340$ \\
\hline Ash & $4.58 \pm 0.284$ \\
\hline Available carbohydrates & $77.69 \pm 0.485$ \\
\hline Total carbohydrates & $83.34 \pm 0.347$ \\
\hline
\end{tabular}


Barros et al. (2010) found that mallow leaves contain $76.30 \%$ moisture, $12.15 \%$ protein, $2.76 \%$ fat, $13.53 \%$ ash and $71.46 \%$ carbohydrates (on dry weight basis). Tabaraki et al. (2012) found that moisture content of Malva sylvestries leaves ranged from 82.8 to $86.23 \%$, protein content ranged from 2.4 to $3.2 \%$, ash content ranged from 13.1 to $14.8 \%$, crude fibre content ranged from 2.9 to $5 \%$ and fat content ranged from 0.16 to $0.3 \%$.

2. Yield, total phenolics, total flavonoids, total tannins and saponins of mallow extracts

The results in Table (2) show that maximum extraction yield was obtained using water as solvent followed by that obtained using methanol but the lowest extractionyield was obtained using $70 \%$ ethanol. This result may be attributed to the substances which soluble in water such as polyphenolics, free amino acids, sugars, some vitamins and some minerals more than those soluble in alcohols.

The results in the same Table show that the amount of total phenolics and total flavonoids of mallow leaves extracted by water were significantly higher than those extracted by $70 \%$ ethanol and $95 \%$ methanol. The amount of total phenolics and flavonoids were higher than those found by Conforti et al. (2008) who found that total phenolics and total flavonoids of dried mallow leaves were $28 \pm 0.35 \mathrm{mg} \mathrm{ACE} / \mathrm{g}$ and $4.77 \mathrm{mg}$ rutin $/ 100 \mathrm{~g}$, respectively. Beghdad et al. (2014) determined the extraction yield, total phenolics and total flavonoids extracted from mallow leaves using $96 \%$ ethanol and found that these parameters were $26.14 \%, 24.12 \mathrm{mg}$ gallic/g and 5.69 $\mathrm{mg}$ rutin/100g dry weight, respectively. The differences between the obtained results and these findings can be attributed to the different solvents used in the extraction process.

Total tannins content of $70 \%$ ethanolic mallow extract was the highest value (15.52 $\mathrm{mg}$ Tannic/g) followed by the value of water extract $(8.64 \mathrm{mg} \mathrm{Tannic/g})$ but the methanolic extract had the lowest one (4.99 $\mathrm{mg}$ Tannic/g) as shown in Table (2). The obtained results for tannins content were higher than that found by Tabaraki et al. (2012), who found the tannins content in mallow leaves extracted by $70 \%$ ethanol for 2 hrs ranged from 1.86 to $2.18 \mathrm{mg} / \mathrm{g}$.In fact, the effects of tannins are mainly related to their interaction with proteins and tanninprotein complexes insoluble, consequently, protein digestibility is decrease.

Table (2). Yield, total phenolics, total flavonoids, total tannins and saponins of mallow extracts obtained using deferent solvents

\begin{tabular}{|l|c|c|c|}
\hline \multirow{2}{*}{ Component } & \multicolumn{3}{|c|}{ Solvent type } \\
\cline { 2 - 4 } & $70 \%$ ethanol & $95 \%$ methanol & Water \\
\hline Extraction yield\% & $16.42 \pm 0.17 \mathrm{c}$ & $18.84 \pm 0.1 \mathrm{~b}$ & $23.03 \pm 0.1 \mathrm{a}$ \\
\hline Total phenolics (mg gallic/ g) & $57.30 \pm 0.04 \mathrm{~b}$ & $43.29 \pm 0.53 \mathrm{c}$ & $121.69 \pm 1.34 \mathrm{a}$ \\
\hline Total flavonoids (mg quercetin /g) & $11.00 \pm 0.01 \mathrm{~b}$ & $11.03 \pm 0.01 \mathrm{~b}$ & $14.01 \pm 0.01 \mathrm{a}$ \\
\hline Total tannins (mg tannic/ g) & $15.52 \pm 0.007 \mathrm{a}$ & $4.99 \pm 0.004 \mathrm{c}$ & $8.64 \pm 0.009 \mathrm{~b}$ \\
\hline Total saponins (mg cholesterol/g) & $6.07 \pm 0.008 \mathrm{a}$ & $4.56 \pm 0.04 \mathrm{~b}$ & ND $^{*}$ \\
\hline
\end{tabular}

Values are the means \pm SD of three determinations. *not determined

In each row, means with a similar letter are not statistically significant from each other. 
It could be noted that $70 \%$ ethanolic extract of mallow green parts contains $6.07 \mathrm{mg}$ saponins/g dry sample while its methanolic extract contains $4.56 \mathrm{mg} / \mathrm{g}$. Saponins are one of natural chemical compounds of many secondary plant metabolites which are abundance in various plant species (Hostettmann and Marston, 1995) and have diverse biological properties (De Geyter et al., 2007).

\section{Identification and quantification} of phenolic compounds of mallow extract

The results of phenolic compounds composition in methanolic extract of mallow green parts $(\mathrm{mg} / \mathrm{kg}$ dry sample) was recorded in Table (3).

Table (3): Composition of the phenolic compounds by HPLC analysis of mallow green parts extract

\begin{tabular}{|c|c|c|}
\hline Phenolic compounds & As ppm & As $\%$ of total \\
\hline Pyrgallol & 575.22 & 15.57 \\
\hline Gallic & 50.03 & 1.35 \\
\hline 4-Amino-benzoic & 10.16 & 0.27 \\
\hline Protocatchuic & 110.37 & 2.99 \\
\hline Catechein & 546.43 & 14.79 \\
\hline Catechol & 19.21 & 0.52 \\
\hline Chlorogenic & 52.94 & 1.43 \\
\hline Epicatachin & 23.39 & 0.63 \\
\hline P-OH-benzoic & 89.86 & 2.43 \\
\hline Caffeine & 76.11 & 2.06 \\
\hline Caffeic & 47.15 & 1.28 \\
\hline Vanillic & 470.32 & 12.73 \\
\hline P-coumaric & 30.28 & 0.82 \\
\hline Ferulic & 141.41 & 3.83 \\
\hline Iso-ferulic & 16.52 & 0.45 \\
\hline e-vanillic & 1137.73 & 30.79 \\
\hline Ellagic & 58.6 & 1.59 \\
\hline Alpha-coumaric & 15.28 & 0.41 \\
\hline Benzoic & 118.24 & 3.20 \\
\hline 3,4,5-methoxy-cinnamic & 7.51 & 0.20 \\
\hline Coumarin & 31.42 & 0.85 \\
\hline Salycilic & 62.8 & 1.70 \\
\hline Cinnamic & 3.93 & 0.11 \\
\hline Total & 3694.91 & 100 \\
\hline
\end{tabular}


Twenty three phenolic compounds were identified and quantified in mallow green parts extract (Table 3 ). It could be observed that e-vanillic is the major phenolic compound where it valued $30.79 \%$ of total phenolic compounds. Shelbaya et al. (2011) found that pyrgallol (1109.65 ppm) is the major phenolic compound in mallow leaves extract. Tabaraki et al. (2012) identified 18 compounds in mallow leaves extract and they found that 2-methoxy -4-vinylphenol was the major phenolic compound. The results in Table (3) indicate also that pyrgallol was the second major compound which amounted $15.57 \%$ followed by catechein (14.79\%), vanillic acid $(12.73 \%)$, ferulic $(3.83 \%)$ and benzoic (3.20\%). The other phenolics were present in low amounts, where each compound valued individually less than $3 \%$ of total phenolic compounds. The results show that coumaric, cinnamic and their derivatives of mallow extract were found in very low amounts.

\section{Identification and quantification of flavonoids of mallow extract Identification of flavonoids} compounds of mallow leaves methanolic extract maintained the presence of 21 flavonoids compound (Table 4) Luteo 6arbinose 8-glucose is the major flavonoid compound in mallow leaves extract, where it valued $27.95 \%$ of total flavonoids followed by Kaemp.3,(2-p-comaroyl) glucose $(19.58 \%)$ and acacetin $(13.32 \%)$. The results show also that hespirdin $(6.98 \%)$, naringenin $(6.23 \%)$ and naringin $4.88 \%$ ) were found to be in moderate amounts. Rosmarinic and apigenin have the lowest amounts in mallow green parts extract. Billeter et al. (1991) identified the flavonoids of $M$. sylvestris leaves extract and found that gossypetin 3-sulphate-8-O- $\beta$-D-glucoside, hypolaetin 3'-sulphate, and three 8hydroxyflavonoids were the major flavonoids constituents.

Table (4): Composition of the flavonoids by HPLC analysis of mallow green parts extract .

\begin{tabular}{|l|c|c|}
\hline Flavonoids & As ppm & As \% of total \\
\hline Luteo 6-arbinose 8-glucose & 967.62 & 27.95 \\
\hline Luteo 6-glucose 8arbinose & 40.28 & 1.15 \\
\hline Apig 6-rhamnose 8-glucose & 106.53 & 3.07 \\
\hline Naringin & 169.39 & 4.88 \\
\hline Apig 6-glucose 8-rhamnose & 22.71 & 0.65 \\
\hline Hespirdin & 241.56 & 6.98 \\
\hline Rutin & 69.11 & 2.00 \\
\hline Quercetrin-3-o-glucoside & 72.73 & 2.10 \\
\hline Rosmarinic & 4.89 & 0.14 \\
\hline Apig. 7-O-neohespiroside & 54.01 & 1.55 \\
\hline Apig. 7-glucose & 41.06 & 1.18 \\
\hline Kaemp. 3,7-dirhamoside & 38.21 & 1.10 \\
\hline Quercetrin & 69.51 & 2.01 \\
\hline Quercetin & 20.69 & 0.60 \\
\hline Kaemp.3,(2-p-comaroyl) glucose & 678.54 & 19.58 \\
\hline Naringenin & 215.84 & 6.23 \\
\hline Hespirtin & 80.86 & 2.33 \\
\hline Kampferol & 34.41 & 0.98 \\
\hline Rhamnetin & 59.85 & 1.72 \\
\hline Apigenin & 12.44 & 0.36 \\
\hline Acacetin & 461.33 & 13.32 \\
\hline Total & 3461.6 & 100 \\
\hline
\end{tabular}




\section{Total Antioxidant Capacity (TAC) of mallow extract}

As shown in Fig. (1), total antioxidant capacity of 500ppm mallow green parts extract separated by $70 \%$ ethanol, $95 \%$ methanol and water decreased as the percentage of water in the solvent decreased. Whereas, the highest $(p<0.05)$ TAC was $(58.7 \pm 0.1 \%)$ detected in the aqueous extract followed by $70 \%$ ethanolic extract (53.5 $\pm 0.4 \%)$, while the 95\% methanolic extract gave the lowest antioxidant capacity (46.5 $\pm 0.4 \%)$. From the results in Table (2) and Fig (1), it could be said that the antioxidant capacity of mallow extract increased with increasing the total phenolics content.

\section{DPPH free radical scavenging activity}

Free radical scavenging is one of the known mechanisms of inhibition of lipid oxidation. In DPPH free radical scavenging assay, antiradical power of an antioxidant is measured as color changes from purple to yellow. It could be used to evaluate hydrogen-donating ability of the compound. The $I_{50}$ value $(p p m)$ is the concentration at which the scavenging activity was $50 \%$ (Min-Sheng Su et al., 2008). Also, $I_{50}$ values denote the concentration of sample, which is required to scavenge $50 \%$ of $\mathrm{DPPH}$ free radicals (Ghasemi et al., 2009). From the results in Table (5), it could be observed that antioxidant activity of the extracts obtained from dried green parts of mallow by different solvents was depending on the type of solvent and concentration of extracts. Where, the inhibition increased gradually with the increasing in concentration of extract. The results show that the highest values of inhibition were found to be in water extract followed by $70 \%$ ethanolic extract meanwhile the lowest values were detected in $95 \%$ methanolic extract at different concentrations. These results indicate that there is a positive relationship between total phenolics content in the extract and its antioxidant activity. The highest value of $I_{50}$ (370 ppm) was obtained in 95\% methanolic extract followed by $70 \%$ ethanolic extract which has 360 ppm and the lowest value (280ppm) was detected in water extract. So, the higher concentration of extract exhibits the higher $I_{50}$ value. These results are in agreement with those mentioned by Beghdad et al. (2014), but they are lower than those reported by Conforti et al. (2008) and Ferreiera et al. (2006).

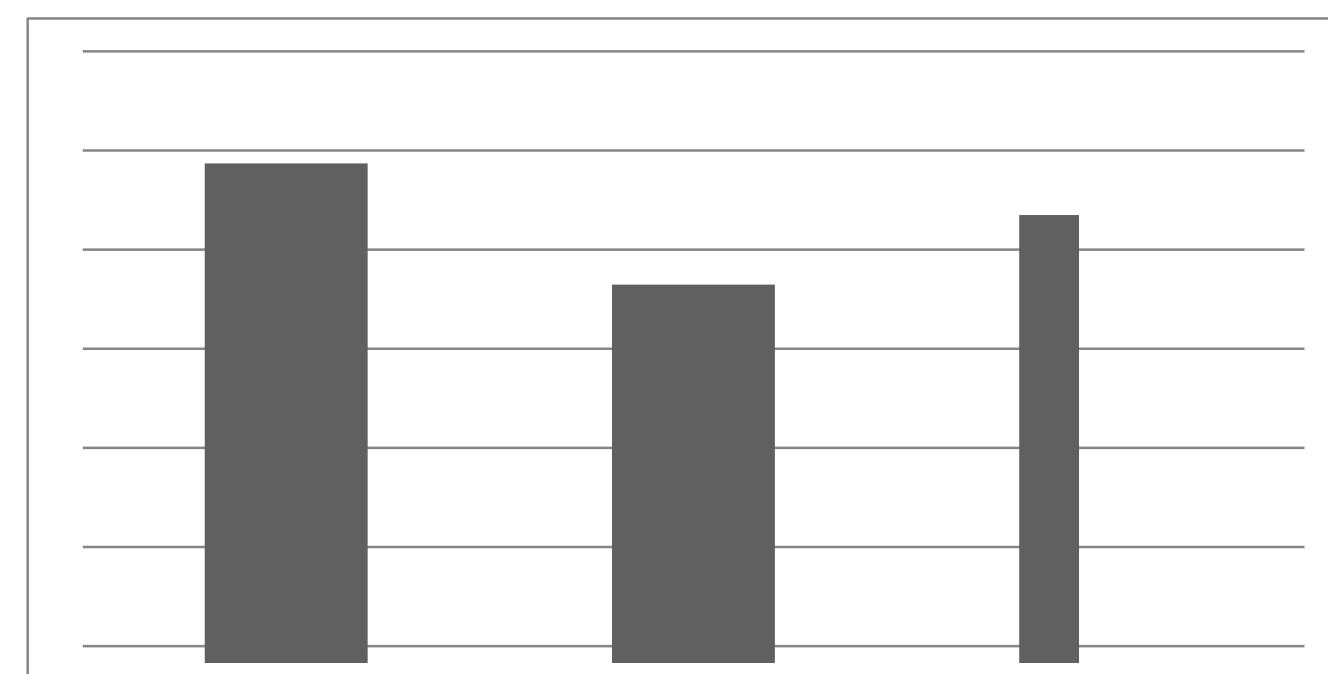

Fig. (1): Total antioxidant capacity (TAC\%) of dried green parts of mallow extracts relating to antioxidant activity of ascorbic acid at $500 \mathrm{ppm}$ 
M. E. El-Sayed, et al.,

Table (5): DPPH free radical scavenging activity (as \% inhibition) of green parts mallow extracts (ppm).

\begin{tabular}{|l|c|c|c|c|l|}
\hline \multirow{2}{*}{ Mallow leaves extracts } & \multicolumn{4}{|c|}{ Inhibition (\%) of DPPH in ppm } & \multirow{2}{*}{$\begin{array}{l}\text { IC } \\
\text { (pp }\end{array}$} \\
\cline { 2 - 6 } & $100(\mathrm{ppm})$ & $200(\mathrm{ppm})$ & $300(\mathrm{ppm})$ & $500(\mathrm{ppm})$ & \\
\hline $70 \%$ ethanol & $29.9 \pm 0.11^{\mathrm{b}}$ & $35.8 \pm 0.5^{\mathrm{b}}$ & $48.9 \pm 0.5^{\mathrm{b}}$ & $67.4 \pm 0.4^{\mathrm{b}}$ & 360 \\
\hline $95 \%$ methanol & $26.7 \pm 1.2^{\mathrm{c}}$ & $32.2 \pm 0.5^{\mathrm{c}}$ & $47.7 \pm 0.5^{\mathrm{b}}$ & $65.8 \pm 1.2^{\mathrm{b}}$ & 370 \\
\hline Water & $35.7 \pm 0.04^{\mathrm{a}}$ & $46.8 \pm 0.5^{\mathrm{a}}$ & $51.6 \pm 0.2^{\mathrm{a}}$ & $77.7 \pm 0.7^{\mathrm{a}}$ & 280 \\
\hline
\end{tabular}

Means \pm Standard deviation for three trails

In a column, means having the same superscript letters are not significantly different at $3 \%$ level

\section{Conclusion}

Green parts of mallow contain consedrable amounts of carbohydrates, protein and ash. Mallow leaves are a rich source for the bioactive compounds such as polyphenolics, flavonoids and saponins. Total antioxidant capacity (TAC) of mallow extracts increased as the percentage of phenolics content increased. Antioxidant activity of the extracts obtained from dried mallow using different solvents was depending on the type of solvent and concentration of extract. Hence, the mallow water extract at $500 \mathrm{ppm}$ had significantly higher antioxidant activity compared to other solvents. Consequently, mallow extracts could be used as natural antioxidants in some types of foods.

\section{REFERENCES}

AOAC Association of Official Analytical Chemists (2005)."Official methods of Analysis ". 13 th Ed., Washington, D.C., U.S.A.

Barros, L., A.M. Carvalho and I.C. Ferreira (2010). Leaves, flowers, immature fruits and leafy flowered stems of Malvasylvestris: A comparative study of the nutraceutical potential and composition. Food Chem. Toxicol.,; 48:1466-1472.

Bennick, A. (2002). Interaction of Plant Polyphenols with Salivary Proteins. Crit. Rev.Oral Biol. Med., 13, 184-196.
Benavente, G. O., J. Lorcnte, J. Castillo, A. Ortno and J. A. Del Rio (2000). Antioxidant activity of phenolic extract from Olea europea L. leaves. Food Chemistry, 68: 457-462.

Beghdad, M.C., C. Benammar, F. Bensalah, F.Z. Sabri, M. Belarbi and F. Chemat (2014). "Antioxidant activity, phenolic and flavonoid content in leaves, flowers, stems and seeds of mallow (Malva sylvestrisL.) from North Western of Algeria". Academic Journals, Vol. 13(3), pp. 486-491

Billeter, M., B. Meier and 0 . Sticher (1991). 8-hydroxyfl avonoid glucuronides from Malva sylvestris. Phytochemistry 30(3):987-990

Charles, D.J., R. Morales and E. Simon (1993). Essential oil content and chemicalcomposition of hydroalcoholic extract of fennel, New crops, 570-573.

Conforti, F., G. loele, G. A. Statti, M. Marrelli, G. Ragno and F. Menichini (2008). Antiproliferative activity against human tumor cell lines and toxicity test on Mediterranean dietary plants.Food Chem. Toxicol. 46:33253332.

Cozzi, R., R. Ricordy, T. Aglitti, V. Gatta, P. Petricone and R. DeSalvia (1997). Ascorbic acid and carotene as modulators of oxidative damage. Carcinogenesis, 18:223-228. 
DeGeyter, E., E. Lambert, D. Geelen and G. Smagghe (2007). Novel Advances with Plant Saponins as Natural Insecticides to Control Pest Insects. Pest Technology, 1: 96-105

Emmons, C. L. and D. M. Peterson (1999). Antioxidant activity and phenolic contents of oats, grouts and hulls. Cereal Chemistry, 76: 902-906.

Evangelisli, F., P. Zunin, E. Tisconia, R. Petacchi, G. Drava and S. Lanteri (1997). Stability to olive conditions: study of polar compounds by chemometric methods. J. of Am. Oil. Chem. Soc., 74:10 17-1022.

Ferreira, A., C. Proença, M.L.M. Serralheiro and M.E.M. Araujo (2006). The in vitro screening for acethyl cholin esterase inhibition and antioxidant activity of medicinal plants from Portugal. J. Ethnopharmacol. 108:31-37.

Ghasemi, K., Y. Ghasemia and M. A. Ebrahimzadeh (2009). Antioxidant activity, phenol and flavonoid contents of 13 citrus species peels and tissues. Pak. Journal of Pharmacological Science.22 (3): 277281

Hiai, S., H. Oura, H. Hamana and Y. Odakea (1975). A color reaction of panaxadiol with vanillin and sulfuric acid. Planta Medica, 28: 131-138

Hostettmann, K. and A. Marston (1995). Saponins. Cambridge: Cambridge University Press. p. 3ff. ISBN 0-52132970-1.OCLC 29670810.

Ito, N., M. Hiroze, G. Fukushima, H. Tauda, T. Shira and M. Tatematsu (1986). Studies on antioxidant: their carcinogenic and modifying effects on chemical carcinogensis. Food and Chemical Toxicology, 24:1071-1081.

Kang, H.J., Chawla c, S.P., Jo b, C., Kwon a, J.H., Byun a, M.W. (2006). Studies on the development of functional powder from citrus peel. Bioresource Technology, 97: 614-620
Karakaya, S. (2004). Radical scavenging and iron-chelating activities of some greens used as traditional dishes in Mediterranean diet. International Journal of Food Sciences and Nutrition, 55: 67-74.

Lako, V.J., C. Trenerry, M. Wahlqvist, N. Wattanapenpaiboon, S. Sotheeswaran and R. Premier (2007). Phytochemical flavonols, carotenoids and the antioxidant properties of a wide selection of Fijian fruit, vegetables and other readily available foods. Food Chemistry, 101: 1727-1741

Laufenberg, G., B. Kunz and M. Nystroem (2003). Transformation of vegetable waste into value added products: (A) the upgrading concept; (B) practical implementations. Bioresearch Technology, 87:167-198.

Lim, Y.Y. and E.P.L. Quah (2007). Antioxidant properties of different cultivars of Portulaca oleracea. Food Chemistry, 103: 734-740

Milin, V. and D. Kustrak (2003): Officinal and unofficinal polysaccharide containing drugs (Mucila genous drugs). Farm Glas . 59: 57-67.

Min-Sheng Su, Yuan-TayShyu and PoJung Chien (2008). Antioxidant activities of citrus herbal product extracts. Food Chemistry, 111: 892896

Paul, D. (2016). A review on biological activities of common mallow (Malva sylvestris L.). Innovare Journal of Life Sciences, 4, 1-5.

Pellegrini, N., B. Colombi, S. Salvatore, O.V. Brenna, G. Galaverna, D. Del Rio, et al. (2007). Evaluation of antioxidant capacity of some fruit and vegetable foods: Efficiency of extraction of a sequence of solvents. Journal of the Science Food and Agriculture, 87: 103-111

Pereira, J.A., I. Oliveira, A. Sousa, P. Valentão, P.B. Andrade, I.C. Ferreira, F. Ferreres, A. Bento, R. Seabra and L. Estevinho (2007). Walnut (Juglans 
regia L.) leaves: phenolic compounds, antimicrobial activity and antioxidant potential of different cultivars. Food Chem. Toxicol. 45: 2287-2295.

Prieto, P., M. Pineda and M. Aguilar (1999). Spectrophotometric quantitation of antioxidant capacity through the formation of a phosphomolybdenum complex: Specific application to the determination of vitamin E. Analytical Biochemistry, 269: 337-341

Reddy, N. and Y. Yang (2005). Biofibers from agricultural byproducts for industrial applications.Trends in Biotechnology, 23: 22-27

SAS Institute (2003). SAS Users Guide: Statistics. SAS Institute Cary, NC.

Shelbaya, L. A. M., A.A.A. Sello and M.A. Kotp (2011). Antioxidative effect of some Malva sylvestris extracts on oxidation of cotton oil during heating. The $6^{\text {th }}$ Arab and $3^{\text {rd }}$ International Annual Scientific Conference. Faculty of Specific Education Mansoura University - Egypt, April, 13-14.

Tabaraki, R., Z. Yosefi, H. A. A. Gharneh (2012). Chemical composition and antioxidant properties of MalvasylvestrisL. J Res Agric. Sci., 8(1): 59-68.
Tadrus, M.D. (1989). Chemical and Biological Studies on Some BabyFoods. M.Sc. Thesis. Fac. of Agric. Cairo Univ., Cairo, Egypt.

Telli, A., N. Mahboub, S. Boudjeneh, O.E.K. Siboukeur and F. Moulti-Mati (2010). Optimisation des conditions d'extraction des polyphenols de datteslyophilisées, phoenix dactylifera l) variété GHARS. Annales des Sciences et Technologie Vol. 2, No. 2.

Thaipong, K., U. Boonprakob, K. Crosby, L. Cisneros-Zevallos and D. Hawkins Byrne (2006). Comparison of ABTS, DPPH, FRAP, and ORAC assays for estimating antioxidant activity from guava fruit extracts. Journal of Food Composition and Analysis 19: 669675.

Vuong, Q. V., S. Hirun, P. A. Phillips, T. L. K. Chuen, M. C. Bowyer, C. D. Goldsmith and C. J. Scarlett (2014). Fruit-derived phenolic compounds and pancreatic cancer: Perspectives from Australian native fruits. Journal of Ethnopharmacology, 152: 227-242.

Yeole, N.B., P. Sandhya, P.S. Chaudhari and P.S. Bhujbal (2010). Evaluation of Malva sylvestris and Pedalium murex Mucilage as Suspending Agent. International Journal of Pharm. Tech. Research, 2 (1): 385-390. 
تاثير انواع المذيبات علي المركبات الحيويه النشطه المستخرجه من اوراق الخبيزه

محمود إمام عبدالعزيز السيخ ، موسي عبده سالم ، إسماعيل محمود عيسي

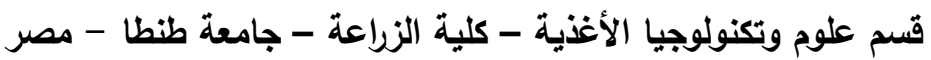

الملخص العربي

تاثير الاستخلاص بالمذيبات المختلفه (كحول ايثانول •v\% و كحول ميثانول ه9\% والمستخلص المائي )علي

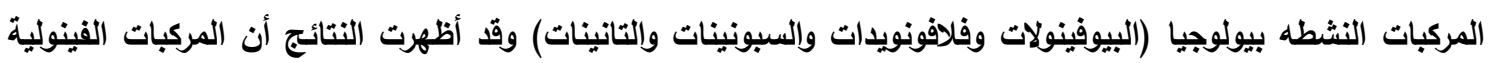

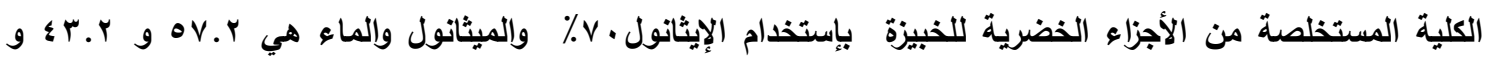

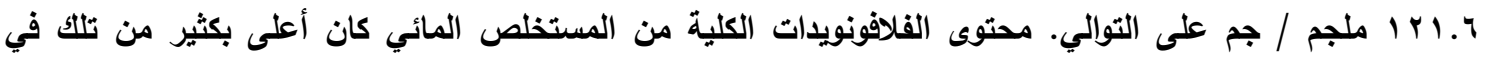

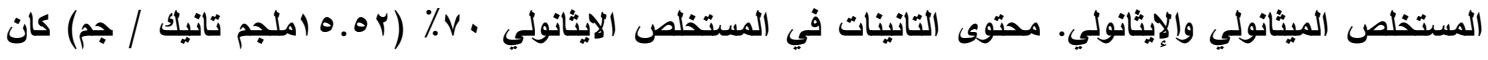

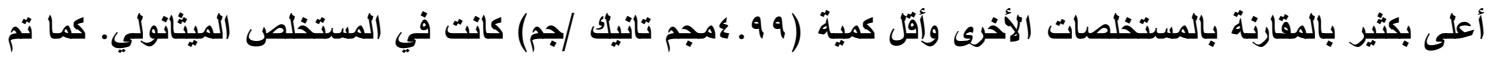

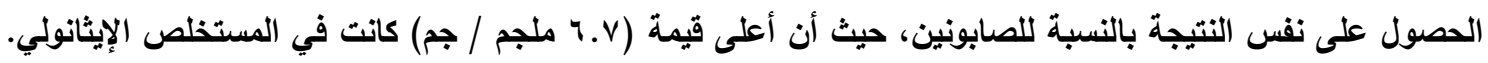

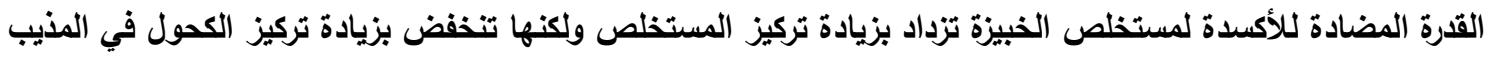

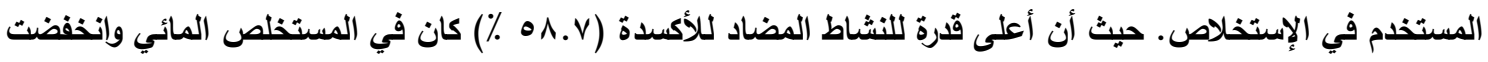

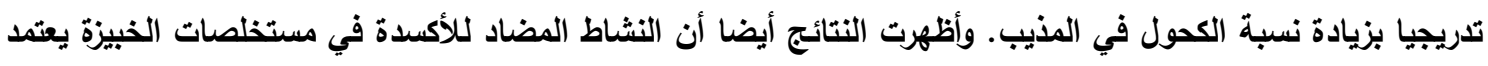

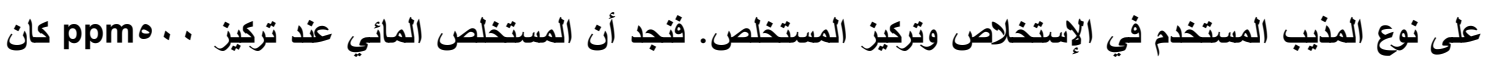

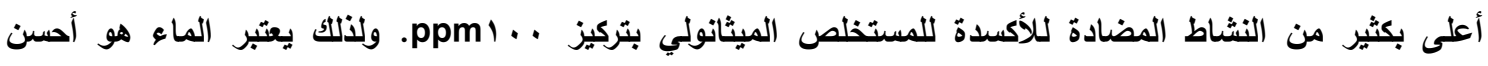

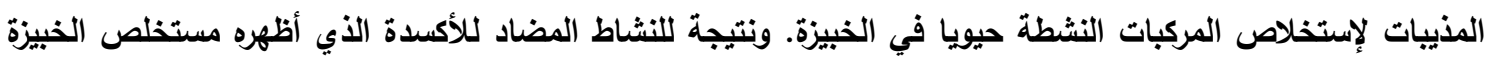
يمكن استخدامه كمضاد أكسدة طبيعي في بعض أنواع الأطعمة. 
M. E. El-Sayed, et al., 